\title{
USE OF ULTRASOUND MEASUREMENTS FOR LAMB FATTENING CONTROL
}

\author{
Dace Barzdina, Daina Kairisa \\ Latvia University of Agriculture \\ daina.kairisa@1lu.lv, dace.barzdina@1lu.lv
}

\begin{abstract}
During the last ten years, the interest in precision farming technologies has increased. Next to crop and horticultural industries, they are also developing for livestock farming purposes. For dairy herds it is dairy management systems, but in meat production used technologies for control of fast growth and assessment of carcass quality. The use of ultrasound for recording purposes of lamb fattening results in Latvia is becoming more and more important. The aim of the research was to explain the changes of the ram (hereafter: lamb) muscle and fat layer depth during the fattening period by using ultrasound technologies. In study 45 fattening lambs are used, of which 24 were meat-type breeds (MT), and 21 Latvian Dark Head with meat-type crossbred (XX) lambs. At the beginning and at the end of fattening the age and live weight of lambs between the research groups did not differ. The Longissimus Dorsi (hereafter: LD) muscle depth of the MT breed lambs was on average 23.6, but XX lambs - $24.1 \mathrm{~mm}$, significant differences were obtained to the fat tissue depth, respectively 2.04 and $1.77 \mathrm{~mm}(p \leq 0.05)$. The MT breed lamb LD muscle depth during fattening increased by an average of $6.05 \mathrm{~mm}$, which is $1.09 \mathrm{~mm}$ more than for the XX group lambs $(p \leq 0.05)$. The depth of fat tissue increase by the research groups was similar on average of $2.0 \mathrm{~mm}$. During intensive fattening of the MT breed lambs per each fatty tissue $\mathrm{mm}$ the depth of muscle increased by an average of $3.09 \mathrm{~mm}$ and for the XX lamb group about $2.94 \mathrm{~mm}$.
\end{abstract}

Keywords: lamb fattening, Longissimus dorsi muscle, fatty tissue, ultrasonic measurement.

\section{Introduction}

Consumers are coming more and more interested in a healthy diet and in animal products that have low fat concentration in carcases with a large proportion of lean meat. Using in consumption animal fat increases a possibility for humans to develop cancer and cardiovascular diseases. For these reasons, it is important to select animals with a lower carcass fat content [1].

The reduction of the fat content in herbivorous animals is a long-term aim in many countries. Animal breeding programs are using animals with a minimum amount of fat in the carcass that improves the quality of live animals' carcass. Sheep carcasses fat content reductions up to optimal levels decrease the production costs and increase the production quality [2].

Lambs are usually fattened in intensive fattening conditions and they are slaughtered immediately after weaning (10 to $12 \mathrm{~kg}$ live weight), or after a short fattening period (from 20 to $30 \mathrm{~kg}$ live weight). As a result carcase conformation and fat become the basic criteria of the quality and price [3].

Carcass quality is an important goal in sheep meat industry. The best quality can be achieved after quantitative and qualitative evaluation of the lamb carcass both in vivo and after slaughter [4].

Nowadays, there are different methods that measure the depth of muscle and fat tissue of live animals. These methods significantly ease the work and also improve the efficiency, rapidness, cost, usability and precision of measurements. One of these methods is ultrasound, which is the most precise to evaluate the quality of the carcass. The ultrasonic technology enables meat producers to predict the time of slaughter, the classification of carcass, the growth of muscle tissue and fat content in different animals [5].

In order for ultrasonic measurement data to be useful for genetic evaluation the evaluation of different traits should be done accurately. Adjustment of ultrasonic measurement requires knowledge of animal growth and development traits, where it is usually one from the two: age or weight [6].

The most common place to evaluate the cross-section depth of lamb muscle and fat tissue is at the $12^{\text {th }}$ to $13^{\text {th }}$ ribs. In some studies higher correlation is obtained between ultrasound and carcass measurements at the $3^{\text {rd }}$ to $4^{\text {th }}$ lumbar vertebrae [7].

The aim of the research was to explain the changes of the lamb muscle and fat layer depth during the fattening period by using ultrasound technologies.

In order to achieve the aim we raised the following tasks:

1. Evaluate the lamb live weight all over the fattening period. 
2. At the beginning and at the end of fattening determine the depth of the LD muscle and fat tissue behind the last $13^{\text {th }}$ rib.

3. Calculate the changes of the LD muscle and fat tissue depth and the ratio of the LD muscle and fat tissue depth.

4. Carry out the correlation analysis of the ultrasonic measurement results with the lamb live weight at the beginning and at the end of fattening.

\section{Materials and methods}

The study is carried out within the Ministry of Agriculture funded project "Different breeds of sheep and their crosses suitability for high-quality carcasses and lamb meat production" framework. In the research the MT breed lambs are used: Charollais (CH), Il-de-France (IF), Suffolk (S), German merino local (GML), Oxford Down (OD), Dorper (DOR) and Latvian Dark Head (LDH) XX lambs with the meat type breeds such as Texel (T), Suffolk, German merino local, Charollais, Hempshire (HEM) and Dorper. In 2016 lamb fattening was carried out in the breeding ram control station "Klimpas". During the research lambs were fed with unlimited combined silage and hay, in addition licks, mineral feed and water were ensured. Lambs at the beginning and at the end of fattening were measured with the ultrasonic equipment Mindray Dp-50 vet with $10.0 \mathrm{MHz}$ transducer and the depth of the LD muscles and fat tissue at the $13^{\text {th }}$ rib was determined.

The calculated changes of the LD muscle and fat depth during fattening as well as the ratio of these changes explain which lamb groups during intensive fattening show the tendency reinforced to form the fatty tissue.

From the resulting measurements the LD muscle and fat tissue depth ratio $(\mathrm{K})$ was calculated before and after fattening of lambs, by using formula:

$$
K=\frac{M}{F},
$$

where $M-$ LD muscle depth, mm

$F-$ fat tissue depth, mm

Analysis of the data was carried out by the scheme as shown in Table 1.

Table 1

Research scheme

\begin{tabular}{|c|c|c|}
\hline $\begin{array}{c}\text { Research } \\
\text { groups }\end{array}$ & Origin (used abbreviation) & $\begin{array}{c}\text { Number of } \\
\text { lambs }\end{array}$ \\
\hline 1 & $\begin{array}{c}\text { Charollais, Il-de-France, Suffolk, Dorper, Germany local } \\
\text { Merino, Oxford Down - meat type (MT) }\end{array}$ & 24 \\
\hline 2 & Latvian Dark Head crossbred lambs (XX) & 21 \\
\hline
\end{tabular}

In the research for data processing mathematical methods are used. In the study the average value of traits, standard error and the coefficient of variation were calculated. The differences between the groups were evaluated with the t-test and the significance was determined with $p \leq 0.05$. The difference in tables is marked with small Latin letters: $a, b, c$, but the fattening results at the beginning and at the end of fattening by using capital Latin letters: A, B, C.

\section{Results and discussion}

In the research lambs with the average age at the beginning of fattening - 85 days or less than 3 months and live weight $26.9 \mathrm{~kg}$ were used, what shows good tendencies in lamb feeding condition during the lactation (Table 2). A similar study in Romania with Teleorman Black Head sheep shows that the live weight at 2.5 months of age reached $22.84 \mathrm{~kg}$ [8]. At the end of fattening the average age of lambs was 151 days, or 5 months and the live weight $-52.9 \mathrm{~kg}$. By the obtained results it can be concluded that the lambs, included in the research, reached the recommended slaughter weight $(40-45 \mathrm{~kg})$ earlier. In the study of other authors the duration of fattening lasted about six months, the slaughter weight of the animals reached an average of $65.23 \mathrm{~kg}$ [4]. The results show that the MT lambs at the beginning of fattening were 2 days older ( $86 \pm 2.2$ days) and about $2.2 \mathrm{~kg}$ heavier 
$(27.9 \pm 1.07 \mathrm{~kg})$ than the XX lambs. At the end of fattening the situation changed, the MT group lambs were 1 day younger $(151 \pm 3.4$ days), but the live weight difference was remained the same as at the beginning of fattening $-2.2 \mathrm{~kg}$, reaching in average of $54.0 \pm 1.11 \mathrm{~kg}$. The biggest live weight at the beginning and the end of fattening was for the GML breed lambs.

Table 2

Average age and live weight of lambs at the beginning and at the end of the fattening period

\begin{tabular}{|c|c|c|c|c|c|c|c|c|}
\hline \multirow{2}{*}{$\begin{array}{c}\text { Research } \\
\text { groups }\end{array}$} & \multicolumn{4}{|c|}{ Age, days } & \multicolumn{4}{c|}{ Live weight, kg } \\
\cline { 2 - 9 } & \multicolumn{2}{|c|}{ beginning } & \multicolumn{2}{c|}{ end } & \multicolumn{2}{c|}{ beginning } & \multicolumn{3}{|c|}{ end } \\
\cline { 2 - 9 } & $\bar{x} \pm S \bar{x}$ & $V, \%$ & $\bar{x} \pm S \bar{x}$ & $V, \%$ & $\bar{x} \pm S \bar{x}$ & $V, \%$ & $\bar{x} \pm S \bar{x}$ & $V, \%$ \\
\hline \multirow{2}{*}{$1 . \mathrm{MT}$} & $\begin{array}{c}86 \\
\pm 2.2^{\mathrm{a}}\end{array}$ & 12.7 & $\begin{array}{c}151 \\
\pm 3.4^{\mathrm{a}}\end{array}$ & 11.1 & $\begin{array}{c}27.9 \\
\pm 1.07^{\mathrm{a}}\end{array}$ & 18.8 & $\begin{array}{c}54.0 \\
\pm 1.11^{\mathrm{a}}\end{array}$ & 10.0 \\
\hline \multirow{2}{*}{$2 . \mathrm{XX}$} & $\begin{array}{c}84 \\
\pm 2.2^{\mathrm{a}}\end{array}$ & 7.3 & $\begin{array}{c}152 \\
\pm 3.2^{\mathrm{a}}\end{array}$ & 9.6 & $\begin{array}{c}25.9 \\
\pm 0.56^{\mathrm{a}}\end{array}$ & 9.9 & $\begin{array}{c}51.8 \\
\pm 0.74^{\mathrm{a}}\end{array}$ & 6.5 \\
\hline
\end{tabular}

$a-p \leq 0.05$

Daily weight gain between the both groups did not show significant differences, where in the MT lamb group it reached $402.0 \mathrm{~g}$ per day, but in the XX lamb group $-385.4 \mathrm{~g}$ per day. The calculated coefficient of variation indicates that both at the beginning and the end of fattening by the age and live weight it was squarer $2^{\text {nd }}$ for the research group (XX) lambs.

The results of ultrasonic measurements are summarized in Table 3. At the beginning of lamb fattening for the LD muscle depth between the groups significantly difference was not obtained. The lambs of the $1^{\text {st }}$ group (MT) on average had $23.6 \pm 0.59 \mathrm{~mm}$ and the lambs of $2^{\text {nd }}$ group (XX) according $24.1 \pm 0.60 \mathrm{~mm}$. Within breeds of MT at the beginning of the fattening the smallest muscle depth obtained for 90 days old OD breed lambs $-16.6 \mathrm{~mm}$, but the largest for 111 days old GML breed lambs $-17.0 \mathrm{~mm}$. From the XX group the smallest LD muscle measurement acquired for 94 days old LDH x DOR crossbred lambs $-18.4 \mathrm{~mm}$, but the largest measurement for 68 days old LDH x $\mathrm{CH}$ crossbred lambs $-28.9 \mathrm{~mm}$.

The average fatty tissue was significantly deeper for the MT group lambs $-2.04 \pm 0.09 \mathrm{~mm}$ and the difference with the XX group lambs was $0.27 \mathrm{~mm}(\mathrm{p} \leq 0.05)$. From the MT breeds the lowest fat tissue depth was for 90 days old $\mathrm{S}$ breed lambs $-1.2 \mathrm{~mm}$, but the biggest for 90 days old Oxford Down and for 85 days old $\mathrm{CH}$ breed lambs $-2.7 \mathrm{~mm}$. In the XX lamb group the smallest fat tissue depth was obtained for 89 days old LDH x GML crossbred lambs $-1.2 \mathrm{~mm}$, but the largest for LDH x HEM crossbred lambs $-2.3 \mathrm{~mm}$.

Table 3

Lamb ultrasonic measurements results at the beginning and the end of fattening, $\mathrm{mm}$

\begin{tabular}{|c|c|c|c|c|c|c|c|c|}
\hline \multirow{2}{*}{$\begin{array}{c}\text { Research } \\
\text { groups }\end{array}$} & \multicolumn{4}{|c|}{ LD muscle depth } & \multicolumn{4}{c|}{ Fat tissue depth } \\
\cline { 2 - 9 } & \multicolumn{2}{|c|}{ beginning } & \multicolumn{2}{c|}{ end } & \multicolumn{2}{c|}{ beginning } & \multicolumn{2}{c|}{ end } \\
\cline { 2 - 9 } & $\bar{x} \pm S \bar{x}$ & $V, \%$ & $\bar{x} \pm S \bar{x}$ & $V, \%$ & $\bar{x} \pm S \bar{x}$ & $V, \%$ & $\bar{x} \pm S \bar{x}$ & $V, \%$ \\
\hline \multirow{2}{*}{$1 . \mathrm{MT}$} & $\begin{array}{c}23.6 \\
\pm 0.59^{\mathrm{a}}\end{array}$ & 12.1 & $\begin{array}{c}29.8 \\
\pm 0.51^{\mathrm{a}}\end{array}$ & 8.1 & $\begin{array}{c}2.04 \\
\pm 0.09^{\mathrm{a}}\end{array}$ & 21.1 & $\begin{array}{c}4.0 \\
\pm 0.12^{\mathrm{a}}\end{array}$ & 14.3 \\
\hline $2 . \mathrm{XX}$ & $\begin{array}{c}24.1 \\
\pm 0.60^{\mathrm{a}}\end{array}$ & 11.4 & $\begin{array}{c}29.0 \\
\pm 0.34^{\mathrm{a}}\end{array}$ & 5.3 & $\begin{array}{c}1.77 \\
\pm 0.07^{\mathrm{b}}\end{array}$ & 16.3 & $\begin{array}{c}3.8 \\
\pm 0.13^{\mathrm{a}}\end{array}$ & 15.8 \\
\hline
\end{tabular}

$\mathrm{a}, \mathrm{b},-p \leq 0.05$

At the end of fattening lambs from different research groups reached a similar LD muscle and fat tissue depth. The MT group lamb LD muscle depth was on average $29.8 \pm 0.51 \mathrm{~mm}$ deep, but for the XX group lambs $-18.0 \pm 0.34 \mathrm{~mm}$. The fat tissue depth respectively was $4.0 \pm 0.12 \mathrm{~mm}$ and $3.8 \pm 0.13 \mathrm{~mm}$. The largest LD muscle depth was obtained from 146 days old $\mathrm{S}$ breed lambs -38.1 $\mathrm{mm}$, but in the crossbred group from 166 days old LDH x HEM crossbred lambs (33.2 mm). In other author similar studies with the meat type the animal muscle tissue depth at the end of fattening was from 19.0 to $20.4 \mathrm{~mm}$ and the fatty tissue depth from 1.3 to $6.0 \mathrm{~mm}[9 ; 10]$.

From the obtained results of ultrasonic measurements the LD muscle and fat tissue depth ratio was calculated (Table 4). As shown by the results at the beginning of fattening between the research 
groups the calculated depth of the tissue ratio had a significant difference. For the XX group lambs the tissue ratio was 13.9, which is about 1.9 more than for the MT group lambs $(p \leq 0.05)$.

Table 4

Research groups lamb LD muscle and fat tissue depth ratio

\begin{tabular}{|l|c|c|c|c|c|c|c|c|}
\hline \multirow{2}{*}{$\begin{array}{c}\text { Research } \\
\text { groups }\end{array}$} & \multicolumn{3}{|c|}{ At the beginning of fattening } & \multicolumn{4}{c|}{ At the end of fattening } \\
\cline { 2 - 9 } & $\bar{x} \pm S \bar{x}$ & min. & max. & $V, \%$ & $\bar{x} \pm S \bar{x}$ & min. & max. & $V, \%$ \\
\hline $1 . \mathrm{MT}$ & $12.0 \pm 0.58^{\mathrm{Aa}}$ & 6.2 & 16.6 & 14.3 & $7.6 \pm 0.24^{\mathrm{Ba}}$ & 5.3 & 9.3 & 9.3 \\
\hline $2 . \mathrm{XX}$ & $13.9 \pm 0.54^{\mathrm{AB}}$ & 9.7 & 20.3 & 11.0 & $7.8 \pm 0.29^{\mathrm{Ba}}$ & 5.8 & 10.4 & 17.1 \\
\hline
\end{tabular}

$\mathrm{A}, \mathrm{B}-p \leq 0.05 ; \mathrm{a}, \mathrm{b}-p \leq 0.05$

At the end of fattening the tissue depth ratio in both groups was significantly lower in the MT group by 4.4 , but in the XX group by $6.1(p \leq 0.05)$, reaching up to $7.6 \pm 0.24$ and $7.8 \pm 0.29$. In the study used lamb LD muscle depth measurements during fattening increased by an average of $5.51 \pm 0.48 \mathrm{~mm}$ and the fat tissue depth by about $2.03 \pm 0.09 \mathrm{~mm}$.

The research group lamb LD muscle and fat tissue depth changes during the fattening stage are summarized in Figure 1.

As shown in Figure 1, the results showed that for the MT group lambs during fattening the LD muscle depth to the $13^{\text {th }}$ rib increased on average by $6.05 \pm 0.73 \mathrm{~mm}$; that is $1.09 \mathrm{~mm}$ more than for the XX group lambs $(p \leq 0.05)$. In the MT lamb group the largest LD muscle depth increase was obtained for two $\mathrm{S}$ breed lambs - $12.1 \mathrm{~mm}$ (duration of fattening - 42 days) and $13.5 \mathrm{~mm}$ (duration of fattening - 56 days), but at the XX group LDH x GML - $10.9 \mathrm{~mm}$ (duration of fattening - 48 days). The fat tissue depth increase over the research groups was similar in average of $2 \mathrm{~mm}$. In the MT lamb group the largest fat tissue depth increase obtained for $\mathrm{S}$ breed ram $-2.9 \mathrm{~mm}$. In the XX lambs group the largest fatty tissue depth increases $(3.3 \mathrm{~mm}$ ) were obtained from $\mathrm{LDH}$ x S crossbred $2.8 \mathrm{~mm}$ thick LD muscle depth increase (75 days of fattening).

The calculated LD muscle and fat tissue depth ratio increase indicates to a development of tissue during fattening. The results showed that during intensive fattening for the MT breed lambs on each fatty tissue $\mathrm{mm}$ the LD muscle depth increased on average $3.09 \mathrm{~mm}$, but in the $\mathrm{XX}$ group lambs $2.94 \mathrm{~mm}$. In the MT group the largest ratio was obtained from the $\mathrm{CH}$ breed lambs -6.82 (72 days of fattening) and in the XX group for the LDH x DOR crossbred lamb - 7.91 (69 days of fattening).

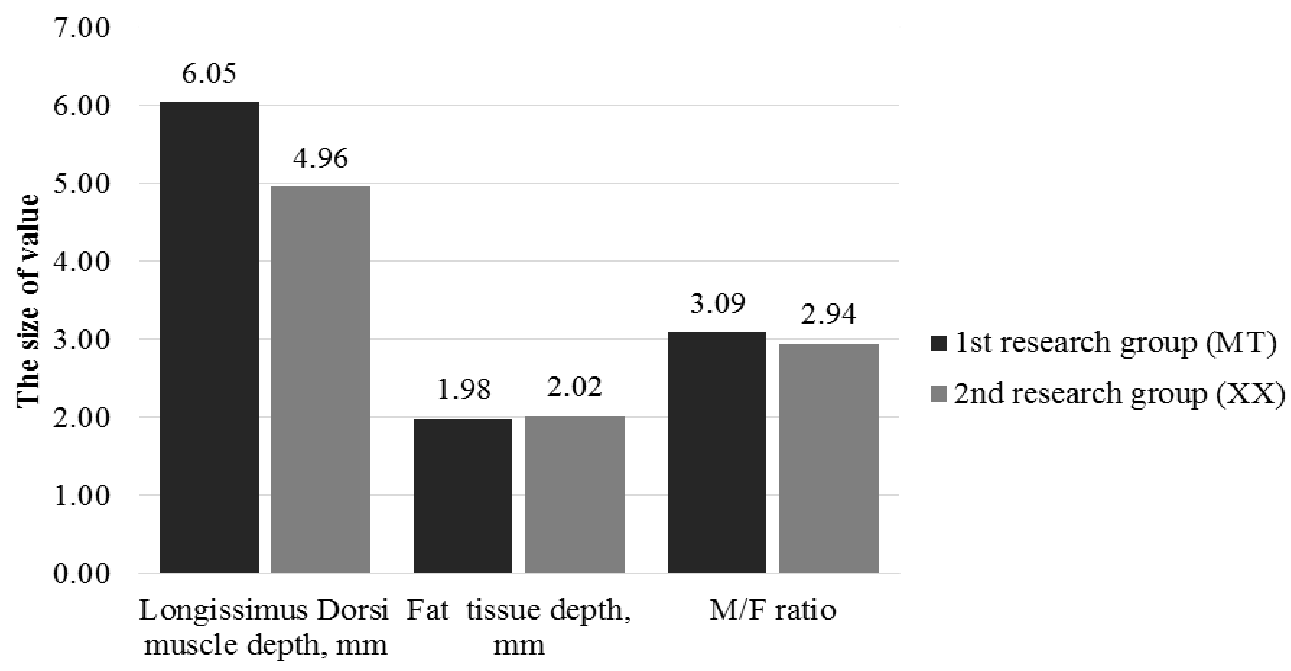

Research values

Fig. 1. LD muscle and fat tissue depth changes during fattening, $\mathbf{m m}$

Lamb age and live weight correlations with the ultrasonic measurement results are summarized in Table 5. As shown by the correlation coefficient, weak positive correlation exists between the live weight and LD muscle depth, $r=0.27$, but the age of the lamb at the beginning of fattening acquired weak negative correlation with the LD muscle depth $(r=-0.11)$. It points out that the study also used breeds of sheep or XX lambs with LD muscle development taking place later. In the study by the 
author M. N. Kiyanzand the correlation between the live weight at the end of fattening and the muscle and fat tissue depth showed similar results to our study, a medium strong positive $r=0.37$ and weak positive $r=0.09$ correlation [2].

Table 5

Correlations with lamb age, live weight and ultrasonic measurement, $\mathbf{m m}$

\begin{tabular}{|c|c|c|}
\hline Signs of research & LD muscle depth & Fat tissue depth \\
\hline \multicolumn{3}{|c|}{ At the beginning of fattening } \\
\hline Lamb age, days & -0.11 & 0.07 \\
\hline Lamb live weight, $\mathrm{kg}$ & 0.27 & -0.10 \\
\hline \multicolumn{3}{|c|}{ At the end of fattening } \\
\hline Lamb age, days & -0.15 & 0.09 \\
\hline Lamb live weight at the end of fattening, $\mathrm{kg}$ & 0.14 & 0.26 \\
\hline Live weight gain during fattening, $\mathrm{kg}$ & -0.02 & 0.33 \\
\hline LD muscle depths at the beginning of fattening, $\mathrm{mm}$ & 0.17 & -0.24 \\
\hline Fat tissue depth at the beginning of fattening, $\mathrm{mm}$ & 0.23 & 0.33 \\
\hline
\end{tabular}

The correlation of the traits at the end of fattening between the lamb age and tissue development remained similar. Live weight gain during fattening showed medium tight positive correlation with the fat tissue depth at the end of fattening $(r=0.33)$. It points to strong connection with changes of the live weight and fatty tissue development. The fat tissue depth preserved a weak positive correlation with the LD muscle depth. A weak negative correlation acquired between the LD muscle depth at the beginning of fattening with the fatty tissue depth at the end of fattening promotes to think that lambs in intensive fattening with weak developed muscles prevail in the fat tissue development. The obtained results confirm the already published results in 2016 that between the fattening characteristics and ultrasound measurements weak correlation exists [11].

\section{Conclusions}

In two months of intensive fattening period:

1. in the MT lamb group the live weight increased by 1.9 times, reaching $54.0 \mathrm{~kg}$, similar to the increased fatty tissue depth -1.97 times, the LD muscle depth increased by an average of $26 \%$ reaching $29.8 \mathrm{~mm}$;

2. in the crossbred lamb group the live weight increased by 2.0 times, reaching $32.2 \mathrm{~kg}$, the fat tissue depth -2.15 times, but the LD muscle depth increased by $20 \%(29.9 \mathrm{~mm})$;

3. in the MT lambs group on each fatty tissue millimetre the LD muscle depth increases by an average of $3.09 \mathrm{~mm}$, but in the crossbred lamb group about $2.94 \mathrm{~mm}$.

The obtained results confirm that the crossbred lambs during the fattening period intensively developed the fatty tissue layer.

Correlations between the lamb age, live weight and ultrasonic measurements showed both a weak positive and weak negative correlation.

\section{References}

1. Orman A., Caliskan G. U., Dikmen S. The assessment of carcass traits of Awassi lambs by realtime ultrasound at different body weights and sexes. American Society of Animal Science, Journal of Animal Science, vol. 88, 2010, pp. 3428-3438.

2. Kiyanzad M. R. Using linear body measurements of live sheep to predict carcass characteristics for two Iranian fat-tailed sheep breeds. Asian-Australasian Journal of Animal Sciences, vol. 17, 2004, pp. 693-699.

3. Esquivelzeta C., Casellas J., Fina M., Piedrafita J. Backfat thickness and longissimus dorsi realtime ultrasound measurements in light lambs. American Society of Animal Science, Journal of Animal Science, vol. 90, 2012, pp. 5047-5055. 
4. Hosseini Vardanjani S. M., Miraei Ashtiani S. R., Pakdel A., Moradi Shahrebabak H. Accuracy of Real-time Ultrasonography in Assessing Carcass Traits in Torki-Ghashghaii Sheep. Journal of Agricultural Science and Technology (JAST), vol. 16, 2014, pp. 791-800.

5. Agamy R., Abdel-Moneim A.Y., Abd-Alla M.S., Abdel-Mageed I.I., Ashmawi G.M. Use of Ultrasound Measurements to Predict Carcass Characteristics of Egyptian Ram-Lambs. Asian Journal of Animal and Veterinary Advances, vol. 10, 2015, pp. 203-214.

6. Emenheiser J. C. Use of ultrasound technology in the genetic improvement of U.S. lamb composition. Thesis for the degree to the faculty of the Virginia Polytechnic Institute, State University, 2009, pp. 109.

7. Thériault M., Pomar C., Castonguay F. W. Accuracy of real-time ultrasound measurements of total tissue, fat, and muscle depths at different measuring sites in lamb. American Society of Animal Science, Journal of Animal Science, vol. 87, 2009, pp. 1801-1813.

8. Lazar C., Gras M.A., Pelmus R.S., Rotar C.M., Ghita E., Burlacu R. Estimation of meat amount by non-linear multiple regression equations using in vivo and carcass measurements on Teleorman Black Head lambs. Journal of Animal and Feed Sciences, vol. 25, 2016, pp. 292-301.

9. Cemal I., Karaca O., Altin T., Gokdal O., Yilmaz M., Yilmaz O. Ultrasound measurements of eye muscle properties and backfat thickness in Kivircik lambs. Journal of Biological Sciences, vol. 7 , 2007, pp. 89-94.

10. Grill L., Ringdorfer F., Baumung R., Fuerst-Waltl B. Evaluation of ultrasound scanning to predict carcass composition of Austrian meat sheep. Small Ruminant Research Journal, vol. 123, 2013, pp. 260-268.

11. Kairisa D., Barzdina D. Quality evaluation of fattening lambs using ultrasonic scanner Mindray DP-50 vet. Proceedings of International Conference "Engineering for rural development", May 25-27, 2016, Jelgava, Latvia, pp. 750-755. 